\title{
SARS-CoV-2 viral load and replication in postmortem examinations
}

\author{
Simone Grassi ${ }^{1}$ (D) Vincenzo Arena ${ }^{2} \cdot$ Paola Cattani $^{3} \cdot$ Marco Dell'Aquila $^{2} \cdot$ Flora Marzia Liotti $^{3}$. \\ Maurizio Sanguinetti ${ }^{3}$. Antonio Oliva ${ }^{1}$. GEMELLI AGAINST COVID-19 group
}

Received: 14 September 2021 / Accepted: 25 November 2021 / Published online: 24 January 2022

(C) The Author(s), under exclusive licence to Springer-Verlag GmbH Germany, part of Springer Nature 2022

\begin{abstract}
We examined 29 autopsy cases (investigated between October 2020 and February 2021) whose postmortem swabs tested positive for SARS-CoV-2. Twenty-two of 29 cases died while hospitalized $(\mathrm{H})$, while the remaining 7 cases were not hospitalized (NH). Since we included only cases in which the time since death was known (excluding unwitnessed NH deaths), the interval between death and postmortem swab(s) was registered, with a mean $\mathrm{NH}$ value of 5.50 days and a mean $\mathrm{H}$ value of 3.98 days. The mean age of $\mathrm{NH}$ was 65 years, while $\mathrm{H}$ were older (mean age: 73 years). Twenty-eight nasopharyngeal and 27 lungs postmortem swabs were obtained and real-time reverse transcriptase-polymerase chain reaction assay for total and replicative SARS-CoV-2 RNA and mRNA detection was performed. Although the mean death-postmortem swabs interval was higher in $\mathrm{NH}$ than in $\mathrm{H}$, the mean viral load of $\mathrm{NH}$ was higher than that of $\mathrm{H}\left(2.53 \times 10^{11}\right.$ copies $/ \mathrm{mL}$ vs $9.31 \times 10^{8}$ copies/ $\mathrm{mL}$ ). In $13 / 29$ cases $(6 \mathrm{NH}$ and $7 \mathrm{H}$ ), indicators of active replication were found. The relationship between the presence of replicative mRNA and death without hospitalization and that between the minimum cycle threshold value of SARS-CoV-2 RNA and the cycle threshold value of replicative SARS-CoV-2 mRNA were found to be statistically significant (with respective $P$ values of 0.013 and 0.000 ). Therefore, especially in $\mathrm{NH}$, full compliance with guidelines on biological safety in the autopsy room is essential, and no autopsy can be performed on infected cases in a structure that does not meet the established safety criteria.
\end{abstract}

Keywords Forensic autopsy $\cdot$ Clinical autopsy $\cdot$ SARS-CoV-2 $\cdot$ COVID-19 $\cdot$ Viral load $\cdot$ Viral replication

\section{Introduction}

V.A. and S.G. equally contributed and thus should be considered co-first authors.

A.O., M.S., and F.M.L. are co-senior authors.

Simone Grassi

simone.grassi@unicatt.it

1 Section of Legal Medicine, Department of Health Surveillance and Bioethics, Fondazione Policlinico A. Gemelli IRCCS, Università Cattolica del Sacro Cuore, Largo F. Vito 1, 00168 Rome, Italy

2 Institute of Anatomical Pathology, Department of Woman and Child Health and Public Health, Università Cattolica del Sacro Cuore, Rome, Italy

3 Dipartimento Di Scienze Di Laboratorio E Infettivologiche, Dipartimento Di Scienze Biotecnologiche Di Base, Cliniche Intensivologiche E Perioperatorie, Università Cattolica del Sacro Cuore, Rome, Italy
During the pandemic, autopsies have been and are crucial both to find the actual cause of death in patients affected by SARS-CoV-2 infection and to collect information for public health (epidemiological) and research purposes [1-5]. Indeed, even in countries (such as the members of the European Union) where there are strict regulatory frameworks regarding privacy protection, during the pandemic, an unprecedented quantity of health data obtained from both clinical settings and autopsies, even without the consent of the patients/families, has been allowed [6]. The remarkable public interest related to autopsies of SARS-CoV-2-positive cases is clear; however, some authors advocated for a restriction of the number of performed autopsies to contain the biological risk for the autopsy room operators [7]. In general, several lines of evidence and guidelines on safety in forensic and clinical autopsies have been published thus far [8-13]. 
On the other side, there is relatively little evidence on the potential hazard of autopsies to personnel and the viability of the virus on the deceased.

In 2020, Dell'Aquila et al. reported qualitative postmortem data (positive vs negative postmortem swabs in cadavers with SARS-CoV-2 infection) from a study population composed of 12 cases of clinical autopsies [14]. DeinhardtEmmer et al. found high viral loads $\left(>10^{4}\right.$ copies $/ \mathrm{mL}$ ) in the lungs of 11 autopsy cases (postmortem interval: $1.5-15.0 \mathrm{~h}$ ) [15]. In 2021, Sablone et al. investigated the presence of viral RNA in 5 forensic autopsies (postmortem interval: 22-27 days), expressing the results in terms of cycle threshold $(\mathrm{Ct})$ value [16]. Plenzig et al. examined four infected cases, succeeding in isolating SARS-CoV-2 in swabs and tissue samples of two forensic cases, one of which died 17 days before and had visible signs of decomposition [17].

It is important to assess this risk because in the autopsy room, both contaminated tissues/fluids and the cadaver surface itself (which can act as a fomite) are possible sources of infection. For instance, Schröder et al. examined 33 cases with antemortem microbiological and clinical evidence of COVID-19, performing swabs on their skin and the body bags/coffins. They did not find viable virus on these surfaces [18].

Furthermore, differentiation between infected persons who died during hospitalization and those who had not received any treatment (who died outside the hospital) would be important to reliably assess this risk. Real-time polymerase chain reaction is an excellent technique to investigate the viral load and replication of SARS-CoV-2 [19, 20]. Wölfel et al. studied nine hospitalized patients with COVID-19 and found a peak of $7.11 \times 10^{8}$ RNA copies per throat swab of infectious virus on day 4 [20]. Active virus replication was also proven to find (subgenomic) SARS-CoV-2 mRNAs in samples since viral subgenomic mRNA is transcribed only in infected cells [20].

We performed a retrospective analysis of cases that tested positive for SARS-CoV-2 after death and underwent forensic investigation or clinical autopsy. In each case, we quantified the total (genomic) SARS-CoV-2 RNA, the replicative (subgenomic) SARS-CoV-2 mRNA, and the viral load in order to evaluate the persistence and the active replication of the virus after death.

\section{Materials and methods}

\section{Patients and specimen collection}

The study population was composed of 29 autopsy cases (17 forensic autopsies and 12 clinical autopsies) investigated between October 2020 and February 2021 at the Fondazione Policlinico Universitario Agostino Gemelli IRCCS in Rome,
Italy. Twenty-two of 29 cases died while hospitalized. In our morgue, postmortem swabs are routinely performed, and we included only cases in which postmortem swabs tested positive for SARS-CoV-2. All the hospitalized cases $(\mathrm{H})$ had antemortem positive tests, while no antemortem microbiological information was available for non-hospitalized cases (NH). We included cases who died outside hospital (NH) only if death was witnessed and thus, the time since death was known (and reported by police and/or public health authorities). The mean age of the $\mathrm{NH}$ was 65 years, while the $\mathrm{H}$ were older (mean age: 73 years). Swab samples were collected from the nasopharyngeal tract (28 swabs: 6 in $\mathrm{NH}$ and 22 in $\mathrm{H}$ ) and/or lungs (27 swabs: 6 in $\mathrm{NH}$ and 21 in $\mathrm{H})$. They were preserved in universal transport medium (UTM, Copan S.p.A., Italy) and stored at $2-8{ }^{\circ} \mathrm{C}$ until testing by real-time reverse transcriptase-polymerase chain reaction (rRT-PCR) assay for total and replicative SARSCoV-2 RNA and mRNA detection, respectively, according to previously described protocols [21]. The interval between death and postmortem swab(s) was registered: In NH, the mean value is 5.50 days (ranging from 0 to 14 days), and in $\mathrm{H}, 3.98$ days (ranging from 0 to 16 days). Samples were processed on Seegene NIMBUS Automated Liquid Handling Workstations, from nucleic acid extraction (using STARMag Universal Cartridge kit) to PCR setup, according to the manufacturer's directions (Arrow Diagnostics, Genova, Italy). Procedures to prevent specimen contamination and PCR carryover were in accordance with standard laboratory practices. Every 2 weeks, naso-pharyngeal swabs were performed on all the members of the teams that performed the autopsies, and these swabs were processed following the same procedures as used for the postmortem samples. All procedures were in accordance with the 1964 Helsinki Declaration and its later amendments or comparable ethical standards. Data were processed in compliance with the European Union General Data Protection Regulation.

\section{Total SARS-CoV-2 RNA detection and quantification}

Total viral RNA was detected by the commercially available Seegene Allplex ${ }^{\mathrm{TM}}$ SARS-CoV2 Assay kit (Arrow Diagnostics, Genova, Italy), a multiplex real-time PCR for simultaneous detection of 4 target genes of SARS-CoV-2 in a single tube: the RdRP/S and N genes specific for SARS-CoV-2, and the E gene for all Sarbecoviruses, including SARS-CoV-2, as in the WHO-recommended protocols. Multiplex RT-PCR was performed on a Bio-Rad CFX96 ${ }^{\mathrm{TM}}$ real-time detection system (Bio-Rad, Italy), and each RT-PCR provided a Ct value, the number of cycles required for the fluorescent signal to cross the threshold for a positive assay. Seegene automated data analysis software (Seegene Viewer) was used to identify positive detections. In particular, a positive result (i.e., a $\mathrm{Ct}$ value lower than 40 ) for at least one of two viral 
genes (i.e., RdRP/S and $\mathrm{N}$ ) or for the $\mathrm{E}$ gene alone indicated the certain or presumptive presence of SARS-CoV-2 RNA in the sample, respectively.

Total viral RNA quantification was performed using the Quanty COVID-19 assay (Clonit S.r.l, Milan, Italy). Separate PCR microplate wells were each filled with $5 \mu \mathrm{L}$ of sample extracted RNA (i.e., derived from the Nimbus RNA extraction step), positive control, negative control, and standards. The viral load in the swab sample was calculated by interpolation of the corresponding $\mathrm{Ct}$ value with a standard curve, which was previously built with the $\mathrm{Ct}$ values obtained following PCR amplification of samples containing $10^{1}, 10^{2}, 10^{3}, 10^{4}$, and $10^{5}$ copies $/ \mu \mathrm{L}$ of synthetic viral N1-encoding RNA [21].

\section{Replicative SARS-CoV-2 mRNA detection}

Postmortem swab samples were also analyzed for subgenomic viral RNA (i.e., E gene replicative/intermediate RNA), which is intended as a surrogate for virus replication, using an in-house RT-PCR assay, as described elsewhere [20]. Specifically, the QIAGEN® oneStep RT-PCR Kit (Qiagen, Valencia, CA, USA), $600 \mathrm{nM}$ of each of two primers (sgE_SARS-CoV2_F 5'-CGATCTCTTGTAGAT CTGTTCTC-3'; sgE_SARS-CoV2_R 5'-ATATTGCAGCAG TACGCACACA-3'), and $200 \mathrm{nM}$ of probe (sgE_SARSCoV2_P 5'-FAM-ACACTAGCCATCCTTACTGCGCTT CG-BBQ-3') were used in a $25-\mu \mathrm{L}$ reaction volume. Thermal cycling consisted of $30 \mathrm{~min}$ at $50{ }^{\circ} \mathrm{C}$ for reverse transcription, followed by $15 \mathrm{~min}$ at $95^{\circ} \mathrm{C}$ and 45 subsequent cycles of $10 \mathrm{~s}$ at $95^{\circ} \mathrm{C}, 15 \mathrm{~s}$ at $55^{\circ} \mathrm{C}$, and $5 \mathrm{~s}$ at $72^{\circ} \mathrm{C}$.

\section{Statistical analysis}

The IBM SPSS Statistics package v. 26.0 was used for statistical analysis. A $P$ value of less than or equal to 0.050 was set as the cutoff for statistical significance. Pearson's chisquared test was performed to investigate five hypotheses: a relationship between the presence of replicative SARSCoV-2 mRNA and death without hospitalization; a relationship between the presence of replicative SARS-CoV-2 mRNA and the minimum Ct value of SARS-CoV-2 RNA (the lowest $\mathrm{Ct}$ value among the $\mathrm{E}, \mathrm{N}$, and RdRP/S genes); a relationship between swab site and the minimum $\mathrm{Ct}$ value of SARS-CoV-2 RNA; a relationship between swab site and the presence of replicative SARS-CoV-2 mRNA; and a relationship between the death-swab interval and the minimum $\mathrm{Ct}$ value of SARS-CoV-2 RNA. Finally, Student's $T$-test was performed to evaluate the relationship between swab site and the viral load.

\section{Results}

Overall, the mean $( \pm \mathrm{SD}) \mathrm{Ct}$ value for $\mathrm{NH}$ was lower than those found for $\mathrm{H}$ (Table 1). These data were confirmed by quantitative RT-PCR of SARS-CoV-2 RNA, which showed mean viral load values of $2.53 \times 10^{11}$ copies $/ \mathrm{mL}$ in $\mathrm{NH}$ and $9.31 \times 10^{8}$ copies $/ \mathrm{mL}$ in $\mathrm{H}$. All samples were also analyzed for replicative SARS-CoV-2 mRNAs. In $13 / 29$ cases ( $6 \mathrm{NH}$ and $7 \mathrm{H}$ ), subgenomic mRNAs were found. The relationship between the presence of replicative mRNA and death without hospitalization and that between the minimum $\mathrm{Ct}$ value of SARS-CoV-2 RNA and the $\mathrm{Ct}$ value of replicative SARS-CoV-2 mRNA (expressed as a positive vs a negative test result) were found to be statistically significant (with respective $P$ values of 0.013 and 0.000) (Tables 2 and 3), while our data do not support a statistically significant relationship between swab site (nasopharyngeal vs lungs) and the minimum $\mathrm{Ct}$ value of SARS-CoV-2 RNA (classified as in Table 3) ( $P$ value: $0.948)$, the presence of replicative SARS-CoV-2 mRNA ( $P$ value: 0.508 ), or the viral load (mean of nasopharyngeal swabs: $1.01 \times 10^{11}$, mean of lungs swabs: $1.21 \times 10^{9}$, value of Levene's Test: 0.054, $P$ value: 0.342 ). Not even the relationship between the death-swab interval (divided into three classes: no more than 2 days, more than 2 days, more than 5 days) and the minimum $\mathrm{Ct}$ value of SARS-CoV-2 RNA (classified as in Table 3) proved to be statistically significant ( $P$ value: 0.063$)$.

All swabs performed on the members of the teams that performed the autopsies were constantly negative.

Table 1 The mean of minimum $\mathrm{Ct}$ values for each swab and the mean viral loads in $\mathrm{NH}$ and $\mathrm{H}$

\begin{tabular}{lll}
\hline & $\mathrm{NH}$ & $\mathrm{H}$ \\
\hline $\begin{array}{l}\text { SARS-CoV-2 (mean } \pm \text { SD Ct } \\
\text { value) }\end{array}$ & $24.64 \pm 9.96$ & $29.42 \pm 7.59$ \\
\begin{tabular}{l} 
Viral load (mean copies $/ \mathrm{mL})$ \\
\hline
\end{tabular} & $2.53 \mathrm{E}+11$ & $9.31 \mathrm{E}+08$ \\
\hline
\end{tabular}

Table 2 Death while hospitalized (yes/no) vs presence of replicative mRNA (yes/no)

\begin{tabular}{lllll}
\hline & & \multicolumn{2}{l}{$\begin{array}{l}\text { Presence of replicative } \\
\text { mRNA }\end{array}$} & Total \\
\cline { 3 - 4 } & & No & Yes & \\
\hline Hospitalization & Yes & 15 & 7 & 22 \\
Total & No & 1 & 6 & 7 \\
$P=0.013$ & & 16 & 13 & 29 \\
\hline
\end{tabular}


Table 3 Presence of subgenomic mRNA vs mCT (i.e., the lowest $\mathrm{Ct}$ value among the E, N, and RdRP/S genes)

\begin{tabular}{lllllll}
\hline & & \multicolumn{2}{l}{$\mathrm{mCt}$} & & Total \\
\cline { 3 - 6 } & & $\mathrm{mCt}<20$ & $20 \leq \mathrm{mCt}<30$ & $30 \leq \mathrm{mCt}<40$ & $\mathrm{mCt}>40$ & \\
\hline Subgenomic mRNA & Negative & 0 & 5 & 25 & 5 & 35 \\
& Positive & 9 & 10 & 1 & 0 & 20 \\
Total & & 9 & 15 & 26 & 5 & 55 \\
$P=0.000$ & & & & & \\
\hline
\end{tabular}

\section{Discussion}

In our paper, we investigated the SARS-CoV-2 viral load, the total (genomic) SARS-CoV-2 RNA, and the presence of mRNA indicating active replication in the postmortem swabs of 29 cases $(22 \mathrm{H}$ and $7 \mathrm{NH}$ ). The mean death-swab interval was higher in $\mathrm{NH}$ than in $\mathrm{H}$ (5.50 days vs 3.98 days), and the mean viral load of $\mathrm{NH}$ was higher than that of $\mathrm{H}$ $\left(2.53 \times 10^{11}\right.$ copies $/ \mathrm{mL}$ vs $9.31 \times 10^{8}$ copies $\left./ \mathrm{mL}\right)$. In $13 / 29$ cases $(6 \mathrm{NH}$ and $7 \mathrm{H})$, indicators of active replication (viral subgenomic mRNAs in biological samples) were found. Moreover, those who died without hospitalization (and then without treatment for the infection) tended to show postmortem viral activity (and thus a higher risk of infection for the autopsy room operators), meaning that according to these data, autopsies of untreated SARS-CoV-2 patients could be associated with a higher biological risk. Finally, replicative mRNA was more frequently detected in samples with low $\mathrm{Ct}$ values (as expected since lower $\mathrm{Ct}$ values correspond to higher viral loads). Our data do not support a statistically significant relationship between swab site (nasopharyngeal vs lungs) and the minimum Ct value of SARS-CoV-2 RNA, the presence of replicative SARS-CoV-2 mRNA, or the viral load. Moreover, the Student's T-test performed on the means of the viral loads of nasopharyngeal and lungs swabs failed to find statistically significant difference. Therefore, consistently with previous evidence [14], our data confirm that multiple swabs of different organs should be performed to reliably assess the postmortem presence (and quantity) of SARS-CoV-2.

Not even the relationship between the death-swab interval and the minimum $\mathrm{Ct}$ value of SARS-CoV-2 RNA proved to be statistically significant. This latter evidence is interesting because it may suggest that also other variables should be taken into account: for instance, postmortem changes (and, in particular, autolysis) may release viral components in the extracellular space and thus influence the postmortem viral load.

Our findings are limited by the fact that the detection of the SARS-CoV-2 genome is not a certain proof of viability of the virus and RT-PCR is not a viral culture (thus, it cannot provide certain information about whether the virus is viable and transmissible). However, viral subgenomic mRNAs are transcribed only in infected cells and are poorly incorporated into mature virions and thus can be considered a marker for actively replicating viruses. The detection of viral replicative RNA intermediates (i.e., E gene subgenomic mRNAs) in samples with $\mathrm{Ct}$ values $\leq 30$ suggests the replicative activity of SARS-CoV-2 in these samples. These data are in accordance with virological and epidemiological data showing that SARS-CoV-2 culture positivity declined with increasing PCR Ct values and that infectivity (as defined by growth in cell culture) was significantly reduced when RT-PCR Ct values were $>30-33[22,23]$. That being said, one of the most interesting findings of our study is that many of our cases showed relatively high viral loads even several days after death. Relatively little evidence on viability in cadavers has been reported so far, albeit several lines of evidence on the virus viability on different kinds of inanimate surfaces have been described in scientific literature. For instance, SARS-CoV-2 may remain viable for 4 days on glass and wood, for 4-5 days on paper, and for 5 days on ceramic, plastic (e.g., Teflon), and metallic surfaces [24-26]. Chin et al. found that in a room with a temperature of $22{ }^{\circ} \mathrm{C}$ and a relative humidity of $65 \%$, trace amounts of virus could be detected on a surgical mask on day 7 [27]. Sizun et al. found that coronaviruses can remain infective for up to $6 \mathrm{~h}$ on latex surgical gloves and for up to $12 \mathrm{~h}$ on sterile sponges after drying for various times [28]. In general, the stability of this virus largely depends on the environmental temperature, relative humidity, and characteristics of the surface (the virus remains viable for a longer time on nonporous surfaces) [29]. Our results confirm that autopsies of SARS-CoV-2-positive cases are associated with a consistent biological risk since the virus remains viable and with a high load for (at least) several days (in our study, up to 16 days) after death. Moreover, in the absence of clinical or anamnestic data, our study prompts extreme caution in the handling of all corpses since a negative clinical history for SARS-CoV-2 does not guarantee microbiologically negative yields. Therefore, as recommended, infected cadavers must be investigated by expert operators wearing proper personal protective equipment (unprotected contact with the skin surface and body fluids must be avoided), and these autopsies can only be performed in BSL-3 Autopsy Facilities. In light of our data, particular attention should be given when the victim has not been hospitalized/treated for SARS-CoV-2 infection. Moreover, our study prompts extreme caution 
when handling cadavers when positivity for SARS-CoV-2 with a low PCR Ct is found; our results show that such a finding is highly suggestive of active replication of the virus, even though this result is not definite proof.

Funding Linea D1, Università Cattolica del Sacro Cuore (Recipient: A.O.)

Availability of data and material Data are available on reasonable request to the corresponding author.

\section{Declarations}

Ethics approval, consent to participate, consent for publication The study complies with the principles of Helsinki Declaration and with the requirements of the European Union GDPR regarding consent.

Competing interests The authors declare no competing interests.

\section{References}

1. Sperhake J-P (2020) Autopsies of COVID-19 deceased? Absolutely! Legal Med 47. https://doi.org/10.1016/j.legalmed.2020. 101769

2. Aguiar D, Lobrinus JA, Schibler M et al (2020) Inside the lungs of COVID-19 disease. Int J Legal Med 134.https://doi.org/10.1007/ s00414-020-02318-9

3. Barth RF, Xu X, Buja LM (2020) A call to action. Chest 158.https://doi.org/10.1016/j.chest.2020.03.060

4. Oliva A, Caputo M, Grassi S et al (2020) Liability of health care professionals and institutions during COVID-19 pandemic in Italy: symposium proceedings and position statement. J Patient Saf 16.https://doi.org/10.1097/PTS.0000000000000793

5. Filograna L, Manenti G, Arena V et al (2021) Claimed medical malpractice in fatal SARS-CoV-2 infections: the importance of combining ante- and post-mortem radiological data and autopsy findings for correct forensic analysis. Forensic Imaging 25.https:// doi.org/10.1016/j.fri.2021.200454

6. Malgieri G (2020) Data protection and research: a vital challenge in the era of COVID-19 pandemic. Comput Law Secur Rev 37

7. Sapino A, Facchetti F, Bonoldi E et al (2020) The autopsy debate during the COVID-19 emergency: the Italian experience. Virchows Archiv 476https://doi.org/10.1007/s00428-020-02828-2

8. Burton JL (2003) Health and safety at necropsy. J Clin Pathol 56. https://doi.org/10.1136/jcp.56.4.254

9. Yaacoub S, Schünemann HJ, Khabsa J et al (2020) Safe management of bodies of deceased persons with suspected or confirmed COVID-19: a rapid systematic review. BMJ Glob Health 5.https:// doi.org/10.1136/bmjgh-2020-002650

10. Aquila I, Sacco MA, Abenavoli L et al (2020) Severe acute respiratory syndrome coronavirus 2 pandemic. Arch Pathol Lab Med 144.https://doi.org/10.5858/arpa.2020-0165-SA

11. Lucas SB (1993) HIV and the necropsy. J Clin Pathol 46. https:// doi.org/10.1136/jcp.46.12.1071

12. Nyberg M, Suni J, Haltia M (1990) Isolation of human immunodeficiency virus (HIV) at autopsy one to six days postmortem. Am J Clin Pathol 94.https://doi.org/10.1093/ajcp/94.4.422
13. Nolte KB, Taylor DG, Richmond JY (2002) Biosafety considerations for autopsy. Am J Forensic Med Pathol 23.https://doi.org/ 10.1097/00000433-200206000-00001

14. Dell'Aquila M, Cattani P, Fantoni M et al (2020) Postmortem swabs in the severe acute respiratory syndrome coronavirus 2 pandemic: report on 12 complete clinical autopsy cases. Arch Pathol Lab Med 144.https://doi.org/10.5858/arpa.2020-0362-SA

15. Deinhardt-Emmer S, Wittschieber D, Sanft J et al (2021) Early postmortem mapping of SARS-CoV-2 RNA in patients with COVID-19 and the correlation with tissue damage. eLife 10 . https://doi.org/10.7554/eLife.60361

16. Sablone S, Solarino B, Ferorelli D et al (2021) Post-mortem persistence of SARS-CoV-2: a preliminary study. Forensic Sci Med Pathol. https://doi.org/10.1007/s12024-021-00375-z

17. Plenzig $S$, Bojkova $D$, Held $\mathrm{H}$ et al (2021) Infectivity of deceased COVID-19 patients. Int J Legal Med 135:2055-2060. https://doi. org/10.1007/s00414-021-02546-7

18. Schröder AS, Edler C, Ondruschka B et al (2021) The handling of SARS-CoV-2 associated deaths - infectivity of the body. Forensic Sci Med Pathol 17:411-418. https://doi.org/10.1007/ s12024-021-00379-9

19. Liotti FM, Menchinelli G, Marchetti S et al (2021) Assessment of SARS-CoV-2 RNA test results among patients who recovered from COVID-19 with prior negative results. JAMA Intern Med 181.https://doi.org/10.1001/jamainternmed.2020.7570

20. Wölfel R, Corman VM, Guggemos W et al (2020) Virological assessment of hospitalized patients with COVID-2019. Nature 581.https://doi.org/10.1038/s41586-020-2196-x

21. Liotti FM, Menchinelli G, Marchetti S et al (2021) Evaluation of three commercial assays for SARS-CoV-2 molecular detection in upper respiratory tract samples. Eur J Clin Microbiol Infect Dis 40.https://doi.org/10.1007/s10096-020-04025-0

22. Zou L, Ruan F, Huang M et al (2020) SARS-CoV-2 viral load in upper respiratory specimens of infected patients. N Engl J Med 382.https://doi.org/10.1056/NEJMc2001737

23. la Scola B, le Bideau M, Andreani J et al (2020) Viral RNA load as determined by cell culture as a management tool for discharge of SARS-CoV-2 patients from infectious disease wards. Eur J Clin Microbiol Infect Dis 39https://doi.org/10.1007/ s10096-020-03913-9

24. Lai MYY, Cheng PKC, Lim WWL (2005) Survival of severe acute respiratory syndrome coronavirus. Clin Infect Dis 41.https://doi. org/10.1086/433186

25. Chan KH, Peiris JSM, Lam SY et al (2011) The effects of temperature and relative humidity on the viability of the SARS coronavirus. Adv Virol 2011.https://doi.org/10.1155/2011/734690

26. Warnes SL, Little ZR, Keevil CW (2015) Human coronavirus $229 \mathrm{E}$ remains infectious on common touch surface materials. mBio 6. https://doi.org/10.1128/mBio.01697-15

27. Chin AWH, Chu JTS, Perera MRA et al (2020) Stability of SARSCoV-2 in different environmental conditions. Lancet Microbe 1.https://doi.org/10.1016/S2666-5247(20)30003-3

28. Sizun J, Yu MWN, Talbot PJ (2000) Survival of human coronaviruses 229E and OC43 in suspension and after drying onsurfaces: a possible source ofhospital-acquired infections. J Hosp Infect 46.https://doi.org/10.1053/jhin.2000.0795

29. Tiwari A, Patnayak DP, Chander Y et al (2006) Survival of two avian respiratory viruses on porous and nonporous surfaces. Avian Dis 50.https://doi.org/10.1637/7453-101205R.1

Publisher's note Springer Nature remains neutral with regard to jurisdictional claims in published maps and institutional affiliations. 